Øivind Torkildsen, MD,

$\mathrm{PhD}$

Kjell-Morten Myhr, MD,

$\mathrm{PhD}$

Stig Wergeland, MD, $\mathrm{PhD}$

Neurol Neuroimmunol Neuroinflamm

2014;1:e25; doi: 10.1212/ NXI.0000000000000025

\section{TREATMENT-RESISTANT IMMUNE THROMBOCYTOPENIC PURPURA ASSOCIATED WITH LDN USE IN A PATIENT WITH MS \\ OPEN}

Naltrexone is an opiate $\mu$-receptor antagonist approved for treatment of alcohol dependency at a recommended dose of $50 \mathrm{mg} /$ day. The mechanism of action is proposed to be mediated by a normalization of endogenous endorphin levels. Despite few and inconclusive studies (casuistic or open-label), a naltrexone dose of 3-5 mg/day (low-dose naltrexone, LDN) has been suggested to ameliorate a wide range of diseases, especially Crohn disease ${ }^{1}$ and multiple sclerosis (MS). ${ }^{2}$ Its effect in these conditions is mainly advocated by patients via both formal and informal networks. Reluctance among physicians to prescribe naltrexone has encouraged illegal import. Based on safety data from initial marketing studies conducted in the 1970s, naltrexone has generally been considered safe, with no serious side effects or adverse events. We present a case of therapy-resistant immune thrombocytopenic purpura (ITP) after LDN use in a patient with MS.

Case presentation. A 64-year-old Caucasian woman was diagnosed with relapsing-remitting MS in 2012 after an episode of optic neuritis. Her diagnosis was confirmed by MRI fulfilling the MacDonald criteria and by the detection of oligoclonal bands in CSF. Routine blood work at the time of diagnosis and 3 years prior to diagnosis showed nothing abnormal but a mild thrombocytopenia $\left(110 \times 10^{9} / \mathrm{L}\right.$; figure). Follow-up MRI showed new and enlarging lesions, and she was prescribed immunomodulatory treatment with interferon $\beta$. However, due to needle phobia, not previously recognized by the patient or the treating physician, she never started interferon $\beta$ therapy. Instead, encouraged by positive reports from peers on the effect of LDN in MS, she acquired naltrexone from an Internet provider located in Israel and started treating herself with $3 \mathrm{mg} /$ day. She reported a transient positive effect on her MS-related fatigue.

After 3 to 4 months of LDN treatment, she noticed spontaneous formation of bruises and gum bleeding. After 4 months, she experienced profuse gum bleeding during a dental examination. Routine blood count at her general physician's lab showed a thrombocyte count (TPC) below $5 \times 10^{9} / \mathrm{L}$ (reference range $165-387 \times 10^{\%} / \mathrm{L}$ ) without effects on the other blood cells, and she was referred to the Department of Hematology at Haukeland University Hospital. Liver function tests were normal. Other rheumatologic, autoimmune, or infectious causes of low TPC were not detected, and bone marrow smears were consistent with ITP. Due to the temporal relationship between LDN treatment and emergence of ITP symptoms, LDN was considered the most probable cause of her ITP and the medication was discontinued after the diagnosis was made. After a short initial response to prednisolone therapy, TPC again fell below $5 \times 10^{\%} / \mathrm{L}$. Neither IV immunoglobulins nor rituximab in combination with steroids had more than a transient effect on TPC. She underwent splenectomy in May 2014, after which platelet counts stabilized at around $136 \times 10^{\%} / \mathrm{L}$ (figure).

Discussion. ITP is defined as thrombocytopenia (low platelet count) with normal bone marrow findings and the absence of other causes of thrombocytopenia. It is generally considered an autoimmune disease, but the exact cause is unknown. Naltrexone, used against opioid dependency, was found to increase the risk of developing ITP in the initial marketing studies. ${ }^{3}$ LDN is usually taken at a dosage of about $10 \%$ of what was given in the initial studies. Some studies have been conducted on the effect of LDN in MS, with varying results, but without reporting any serious adverse events. ${ }^{2,4,5}$ However, since the use of LDN is largely off-label, no large safety studies have been conducted. Advocates of LDN use have typically pointed out that this medication is completely safe and without any serious side effects. As this case presentation demonstrates, LDN could possibly predispose to an increased risk of developing ITP. Our patient had platelets at about $120 \times 10^{9} / \mathrm{L}$ for at least 3 years prior to diagnosis with ITP, and it is possible that the association with LDN use is spurious. However, since naltrexone use is known to increase the risk of ITP, it is biologically plausible that LDN has either triggered her ITP or aggravated a subclinical disease. This case demonstrates a possible safety concern 


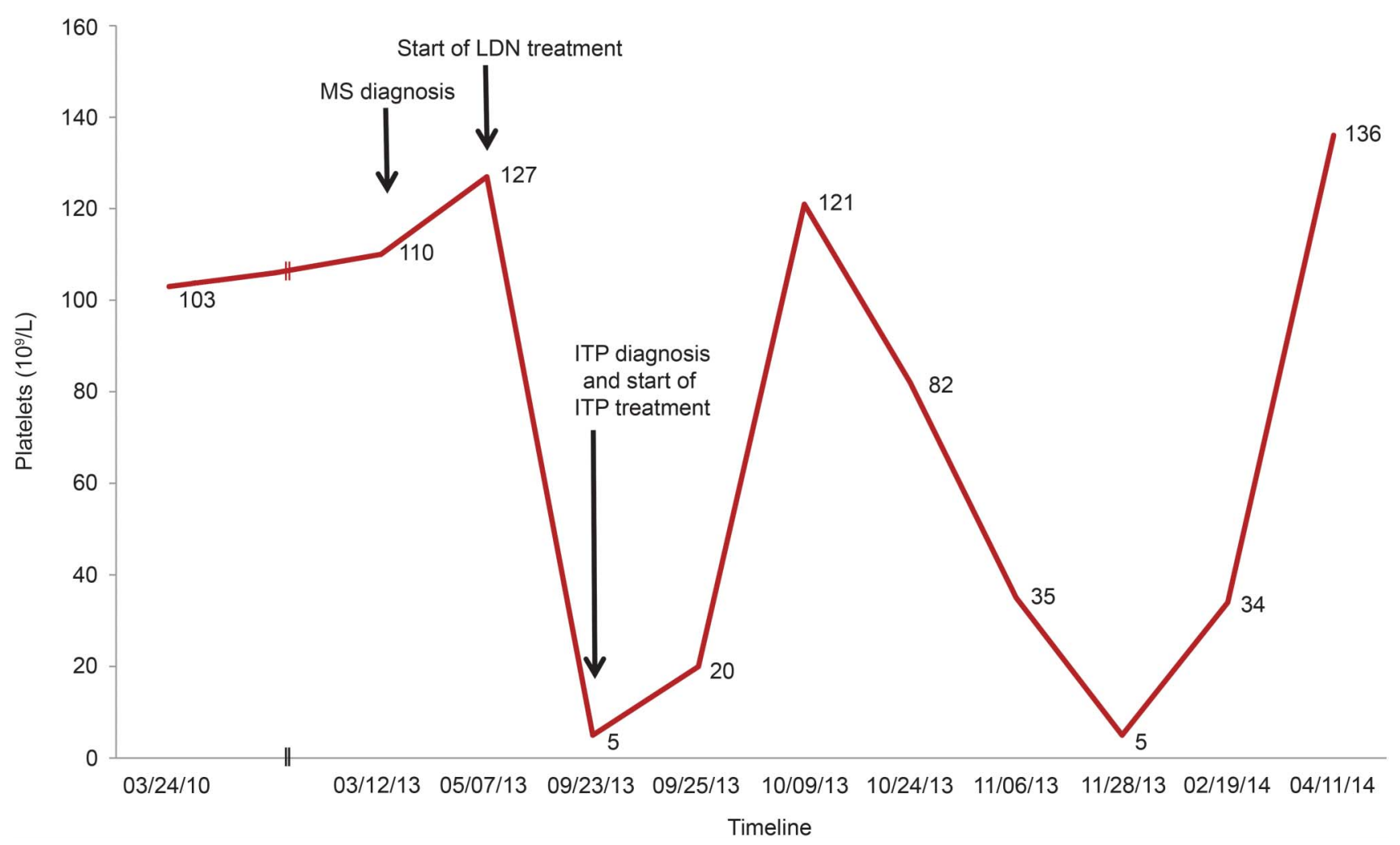

The thrombocyte counts correspond to each date on the $\mathrm{x}$-axis. ITP = immune thrombocytopenic purpura; MS = multiple sclerosis

regarding LDN treatment and the importance of thorough review of patients' on- and off-label drug use.

From the Norwegian Multiple Sclerosis Competence Centre (Ø.T., S.W.) and Norwegian Multiple Sclerosis Registry \& Biobank (K.-M.M.), Department of Neurology, Haukeland University Hospital, Bergen, Norway; and Kristian Gerhard Jebsen MS Research Centre (Ø.T., K.-M.M., S.W.), Department of Clinical Medicine, University of Bergen, Norway.

Author contributions: Study concept and design: Dr. Ø.T., Dr. K.-M.M., and Dr. S.W. Acquisition of data: Dr. Ø.T. and Dr. S.W. Analysis and interpretation: Dr. Ø.T., Dr. K.-M.M., and Dr. S,W. Critical revision of the manuscript for important intellectual content: Dr. Ø.T., Dr. K.-M.M., and Dr. S.W. Study supervision: Dr. Ø.T.

Study funding: No targeted funding reported.

Disclosure: $\varnothing$. Torkildsen has served on a scientific advisory board for Biogen Idec and received speaker honoraria and travel grants from Genzyme, Merck-Serono, Novartis, and Biogen-Idec. K.-M. Myhr is on the scientific advisory board for Novartis Norway, Biogen Idec, and Genzyme; received funding for travel from Bayer, SanofiAventis, Novartis, Merck-Serono, and Biogen Idec; received speaker honoraria from Bayer, Genzyme, Sanofi-Aventis, Novartis, MerckSerono, and Biogen Idec; and received research support from Bayer, Sanofi-Aventis, Novartis, Merck-Serono, Biogen Idec, Pronova Biocare, and Norwegian MS Society. S. Wergeland has received travel funding from Novartis and research support from Western Norway Regional Health Authority. Go to Neurology.org/nn for full disclosures. The Article Processing Charge was paid by the Norwegian Multiple Sclerosis Competence Centre.
This is an open access article distributed under the terms of the Creative Commons Attribution-Noncommercial No Derivative 3.0 License, which permits downloading and sharing the work provided it is properly cited. The work cannot be changed in any way or used commercially.

Received June 16, 2014. Accepted in final form July 17, 2014.

\section{Correspondence to Dr. Torkildsen: oivind.torkildsen@gmail.com}

1. Smith JP, Stock H, Bingaman S, et al. Low-dose naltrexone therapy improves active Crohn's disease. Am J Gastroenterol 2007;102:820-828.

2. Gironi M, Martinelli-Boneschi F, Sacerdote P, et al. A pilot trial of low-dose naltrexone in primary progressive multiple sclerosis. Mult Scler 2008;14:1076-1083.

3. Bradford A, Hurley F, Golondzowski O, Dorrier C. Interim report on clinic intake and safety data collected from 17 NIDA-funded naltrexone studies. NIDA Res Monogr 1976;9:163-171.

4. Cree BA, Kornyeyeva E, Goodin DS. Pilot trial of low-dose naltrexone and quality of life in multiple sclerosis. Ann Neurol 2010;68:145-150.

5. Sharafaddinzadeh N, Moghtaderi A, Kashipazha D, Majdinasab N, Shalbafan B. The effect of low-dose naltrexone on quality of life of patients with multiple sclerosis: a randomized placebo-controlled trial. Mult Scler 2010;16: 964-969. 


\section{Neurology \\ Neuroimmunology \& Neuroinflammation}

\section{Treatment-resistant immune thrombocytopenic purpura associated with LDN use in a patient with MS \\ Øivind Torkildsen, Kjell-Morten Myhr and Stig Wergeland \\ Neurol Neuroimmunol Neuroinflamm 2014;1; \\ DOI 10.1212/NXI.0000000000000025}

This information is current as of August 21, 2014

Updated Information \&

Services

References

Subspecialty Collections

Permissions \& Licensing

Reprints including high resolution figures, can be found at:

http://nn.neurology.org/content/1/3/e25.full.html

This article cites 5 articles, 0 of which you can access for free at: http://nn.neurology.org/content/1/3/e25.full.html\#\#ref-list-1

This article, along with others on similar topics, appears in the following collection(s):

Autoimmune diseases

http://nn.neurology.org//cgi/collection/autoimmune_diseases

Multiple sclerosis

http://nn.neurology.org//cgi/collection/multiple_sclerosis

Information about reproducing this article in parts (figures,tables) or in its entirety can be found online at:

http://nn.neurology.org/misc/about.xhtml\#permissions

Information about ordering reprints can be found online: http://nn.neurology.org/misc/addir.xhtml\#reprintsus

Neurol Neuroimmunol Neuroinflamm is an official journal of the American Academy of Neurology.

Published since April 2014, it is an open-access, online-only, continuous publication journal. Copyright $($ ) 2014 American Academy of Neurology. All rights reserved. Online ISSN: 2332-7812.

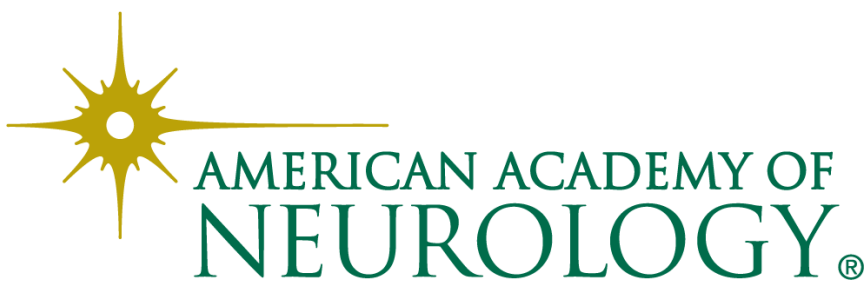

